\title{
Creativity in design and process problems with triz (theory of inventive problem solving)/systematic innovation
}

\author{
Marco Aurélio de Carvalho ${ }^{a}$, Claudinei Garcia Buzinarob , Gustavo Garbuio Brandalizec, Luís Gustavo de Medeiros Chagas ${ }^{a}$ \\ oFederal University of Technology of Parana \\ bMagneti Marelli \\ cElectrolux
}

e-mails: marcoaurelio@uffpr.edu.br; cbuzinaro@gmail.com; gutomil@gmail.com; luisgustavomc@hotmail.com

\begin{abstract}
Can creativity be systematic? Many people have a visceral negative response to this question. Some would say that it is a contradiction, Actually, with strong support from the concept of contradiction, TRIZ (Theory of Inventive Problem Solving)/Systematic Innovation (TRIZ/SI) offers those companies and individual entrepreneurs who are interested in the development of their products and processes, the possibility of systematizing the ideation process. In this article, two examples on the application of TRIZ/SI are presented; one in the conceptual design of a fabric softener dispenser in a washing machine, and the other, in solving a pipe welding problem. Initially, the objective of the study is established. Then, the general methodology utilized in both cases is presented. The cases are then described. Lastly, conclusions are derived based on the results obtained.
\end{abstract}

Keywords: theory of inventive problem solving, systematic innovation, product development, fabric softener distribution, pipe welding.

\section{Introduction}

The need to formalize and incorporate a process for the development of technologies and products that make the creation and release of new solutions to the problems of their clients a part of the daily routine, and not an interruption to that same routine, has become clear to many companies and individual entrepreneurs. More than that, there is a need to find features that differentiate a company's products from what the competitors are offering, many of whom already use systematic processes of development. Therefore, it may be observed that successful companies and entrepreneurs attempt to apply a unique combination of tools and approaches that best adapt to their cultures, markets, and objectives and which may produce the best results.

Although it was created many years ago in the old USSR, broadcast to the rest of the world after the 1990s, and underwent a period of large global expansion during the decade of 2000, the experience of the authors indicates that TRIZ (Theory of Inventive Problem Solving)/Systematic Innovation (TRIZ/SI) has yet to find its proper place in the developmental toolbox for technologies, products, and processes of many Brazilian companies. Many do not know about TRIZ/SI, or have a very limited knowledge of its methods and possible uses. One of the reasons for this is the limited availability of practical materials for those who are interested in learning about and utilizing TRIZ/SI. This article is intended to be a contribution toward the mitigation of this problem.

The objective of this article is to present two cases in which elements of TRIZ/SI were used for the comprehension and resolution of problems in distinct phases of the developmental processes of products. One of them is situated in the conceptual project for a new solution to the distribution of fabric softener in a washing machine. The other case addresses the resolution of a process problem in pipe assembly.

\section{Methodology and cases}

The methodology adopted in the research for this article is that of case study. This methodology allows the problem solver to see the things in a clearer way, from model to theory. Students of TRIZ can then derive the key concepts of the theory from the experiments on their own (ORLOFF, 2003). In both situations here illustrated, the tools which were adopted are those of TRIZ/SI, succinctly described as follows.

Through the use of distilled heuristics derived from the analysis of patents and other sources of information, TRIZ/SI fosters the systematic analysis of problems and their solutions. As a science, TRIZ addresses the problem of determining and categorizing all regular features and 
aspects of technical systems and technological processes that need to be invented or improved, as well as of the inventive process itself (SAVRANSKY, 2000). Although the process may be supported by computational tools, the study in itself is still done in a non-computational manner, as artificial intelligence has not yet reached the flexibility, analytical capacity, creativity, and abstraction which the human mind possesses (DE CARVALHO, 2008).

To adequately apply TRIZ/SI, it is necessary that the problem-solver overcome the so - called psychological inertia, which is responsible for preventing the visualization of solutions outside their area of practice, or even seeing new solutions after the first promising solution has been found. Psychological inertia is analogous with physical inertia, which can be described as the effort made by a system to preserve the current state or to resist changes to that state (SAVRANSKY, 2000).

In this section, concepts and tools of TRIZ/SI which were applied in the case studies described in this article are addressed. In both cases, the Method of Inventive Principles (MIP) and the Method of Separation (MS) were used. Both methods deal with contradictions.

Contradictions are conflicting characteristics in a product or process. In other words, for the evolution of a system one or more negative effects can be found. According to TRIZ/SI, often the most effective inventive solution of a problem is the one that overcomes contradictions (SAVRANSKY, 2000). For example, in the case of computers, there is a technical contradiction between data storage capacity (which manufacturers usually want to increase) and the portability of the product (which gets worse with current solutions for increasing data storage capacity).

Another type of contradiction studied by TRIZ/SI is the physical contradiction. Physical contradictions correspond to opposing values of the same characteristic. An example of such a contradiction is the case of an automobile's bodywork which must be resistant in order to withstand the sustained efforts resulting from the regular use of the vehicle and its own weight, while it must also be able to deform when it suffers powerful impacts (high tenacity so as not to eject the passengers in the case of a collision). This category of contradiction is, normally, the one that tends to bring the most frustration to the problem solver. At first, it seems impossible to resolve, for the idea of a single parameter that has opposing characteristics is inherently unacceptable. Paradoxically, the more impossible the solution to the contradiction may seem, the closer the problem-solver is to the solution (DE CARVALHO; MARTINS, 2010).

The Method of Inventive Principles (MIP) uses 40 Inventive Principles (IPs), which consist of generic suggestions for previously discovered solutions. Some examples of IPs are: Extraction, Inversion, and Segmentation. The 40 IPs were extracted from more than 40,000 patents (SAVRANSKY, 2000).
The most common use for the IPs is the analysis of the technical system, followed by a proposal of solutions based on the direct use of IPs (DE CARVALHO; MARTINS, 2010). Another manner of utilizing the IPs is through the Contradiction Matrix (CM). This matrix unites 39 Engineering Parameters (EPs). These are common parameters found in problems and they can be grouped in three clusters: 1) common physical and geometric parameters (mass, size); 2) technology-independent negative parameters (waste of substance or time, harm); 3) technology-independent positive parameters (productivity, manufacturability) (SAVRANSKY, 2000). They are arranged in the first column (parameters that should be improved) and in the first line of the matrix (parameters that get worse), in such a way that, upon identifying the contradiction between two parameters, one need only search in the matrix which is the intersection of the column of the parameter that one wishes to improve and the jeopardized parameter. The intersection will indicate which IP(s) is(are) (a) probable alternative(s) for reaching a solution to the contradiction. The two cases presented in this paper will show how to apply this technique.

Another method that is commonly utilized in TRIZ/SI is the Method of Separation. Previously, an example of physical contradiction was cited, where it was stated that the body of an automobile must be both rigid and tenacious. Now a question is posed: is it necessary that the body be rigid at all times? The answer to this question is no. Only in an eventual violent impact, the desired outcome is that the body of the car absorbs the greater part of the energy, diminishing the undesired effects upon the passengers. This is the main idea behind the Method of Separation (MS), separate the contradictions into one of four possibilities or Principles of Separation: in Time, Space, According to Condition, and in the System. As a rule, each separation heuristic should be investigated because one cannot predict absolutely which will lead to the most significant breakthrough (SAVRANSKY, 2000).

\subsection{Case 1 - fabric softener dispenser}

In this case, TRIZ/SI was used to search for alternative solutions for the distribution of fabric softener in washing machines. The alternatives that have been found for fulfilling this function in washing machines that are available on the market today are variations around the same technological solution, which is the use of the siphon effect.

This solution has many problems, most of which are well known to product users. At times, the system does not distribute fabric softener. At other times, it distributes the softener at the wrong moment. This may happen during the wash cycle, for example, immediately jeopardizing cleanliness because the softener partially nullifies the effects 
of the soap and, secondarily, it leaves the clothes without softening, because the distribution of the fabric softener occurred at the wrong moment. Another problem stems from the gradual accumulation of softener in the system, forming grout which will, with time, fall on the clothing items and stain them. As seen, there are multiple problems, and the exact causes and mechanisms by which they occur are unclear.

In this case, initially, the modern system was analyzed and an alternative was developed in which the softener does not cease to be applied and is not distributed in a harmful quantity or at the wrong moment.

During the analysis of the system, all possible information on the problem and neighboring topics was researched. The first form used in analyzing the problem was carried out by utilizing the Innovation Situation Questionnaire (ISQ) (TERNINKO; ZUSMAN; ZLOTIN, 1998). A summary for the ISQ itinerary is presented in Table 1 . This is a tool that leads to a full scan of the system in question. Each of the summarized steps is divided into activities.

Still in this stage of formulating the problem, the operating diagram of the system was constructed. In this diagram, one begins with the primary function and follows
Table 1. Summary of the Innovation Situation Questionnaire (ISQ).

1 - Information on the system that needs to be bettered.

Gather basic data on the problem, such as name, function, structure, operation, and related areas.

2 - Available resources.

List the resources: chemical, in the field (electric energy, gravitational potential), current space of the distributor, time, informational, and functional.

3 - Information on the situation of the problem.

Discover which is the desired improvement to the system or what is the problem that should be eliminated; mechanism which causes the problem, if it is clear; developmental history of the problem; other problems that must be solved.

4 - Modifying the system.

Identify the modifications that are permissible by the system; limitations over the changes in the system.

5 - Criteria for selecting conceptual solutions.

Identify the desired technological characteristics; desired economic characteristics; desired schedule; expected degree of innovation.

6 - History of attempted solutions for the problem.

Carry out a study of the existing products on the market; identify the solutions which have been tried within the company itself; research patents.

Modern dispenser solution

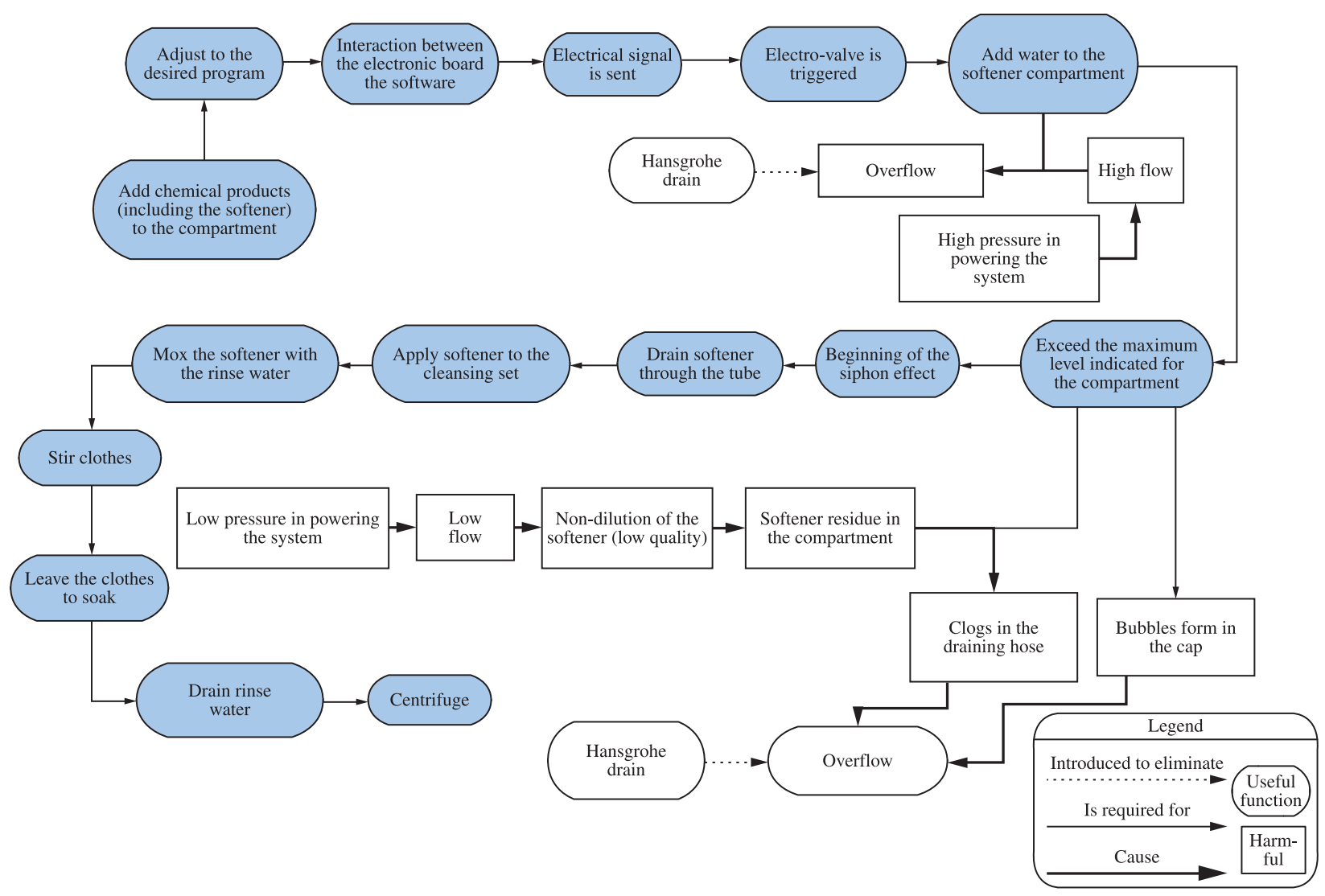

Figure 1. Operating Diagram of the Current Softener Dispenser (BRANDALIZE, 2009). 
through by building on the functions required for the development of subsequent functions. Its objective is to subdivide the primary problem in various smaller problems, liked logically, as presented in Figure 1.

Based on the information collected through the use of the ISQ, the following contradictions were formulated in need of a solution:

- Distribute the softener without causing the dilution of the same and/or leaving fabric softener residue in the compartment;

- Add water to the softener compartment to achieve the minimum level outflow without causing the non-dilution of the fabric softener and/or overflow.
With the problem clearly defined, the MIP was utilized to generate ideas that might overcome the central contradictions that were found. The steps followed are summarized in Table 2.

A Morphological Matrix was utilized to organize and amplify the generation of solutions (Table 3). The functions and principles of operations listed were defined based on the operational diagram presented, as well as solutions identified in competing products, and in the patent bank, apart from those obtained through the use of TRIZ/SI.

The principle concepts that were generated, after the combination of ideas considered to have the greatest potential, are presented in Table 4.

Table 2. Application of the MIP (BRANDALIZE, 2009).

\begin{tabular}{|c|c|c|}
\hline Contradiction as formulated & $\begin{array}{c}\text { Contradiction in } \\
\text { terms of engineering } \\
\text { parameters } \\
\end{array}$ & $\begin{array}{l}\text { Inventive principles indicated by the matrix of contradictions } \\
\text { and ideas generated }\end{array}$ \\
\hline $\begin{array}{l}\text { If the application of the softener is } \\
\text { improved by substituting the system, } \\
\text { than the necessity of developing a new } \\
\text { system is created. }\end{array}$ & $\begin{array}{l}\text { Trustworthiness }(27) \times \\
\text { User convenience }(33)\end{array}$ & $\begin{array}{l}10 \text { - Prior Action: The softener should be diluted before being } \\
\text { utilized in the system. } \\
\text { The system should be clean before it is utilized. } \\
30 \text { - Flexible films or membranes: Utilize a disposable membrane } \\
\text { in the recipient. } \\
\text { Utilize a paint or varnish the eases the cleaning process or which is } \\
\text { self-cleaning. } \\
4 \text { - Asymmetry: Utilize symmetry to make draining the vessel } \\
\text { easier. }\end{array}$ \\
\hline $\begin{array}{l}\text { If the application of the softener is } \\
\text { improved by the dilution of the softener, } \\
\text { than the need for pre-treatment is } \\
\text { created. }\end{array}$ & $\begin{array}{l}\text { Quantity of the substance } \\
(26) \times \text { User convenience } \\
\text { (33) }\end{array}$ & $\begin{array}{l}35 \text { - Transformation of the physical and/or chemical state of the } \\
\text { object: Pre-treatment of the fabric softener before it is used. } \\
29 \text { - Use a hydraulic or pneumatic installation: Utilize a plunger or } \\
\text { piston to increase the level. } \\
\text { Utilize a plunger or piston to expel liquid from the recipient. } \\
25 \text { - Auto-service: The shape of the recipient and the addition of } \\
\text { the water should permit the dilution of the softener and its own } \\
\text { cleaning after each cycle. } \\
10 \text { - Prior action: The softener should be diluted before its use in } \\
\text { the system. } \\
\text { The system should clean before its utilization. }\end{array}$ \\
\hline $\begin{array}{l}\text { If the cleanliness of the system is } \\
\text { improved by diluting the softener, than } \\
\text { the need for pre-treatment is created. }\end{array}$ & $\begin{array}{l}\text { Undesirable factors } \\
\text { acting in an object }(30) \times \\
\text { User convenience }(33)\end{array}$ & $\begin{array}{l}2 \text { - Extraction: Remove the "vehicle" of the softener so as to leave } \\
\text { only those substances of interest. } \\
25 \text { - Auto-service: The shape of the recipient and the addition of } \\
\text { the water should permit the dilution of the softener and its own } \\
\text { cleaning after each cycle. } \\
28 \text { - Substitution for a mechanical system: Use a system similar to } \\
\text { the water mill. } \\
29 \text { - Use a hydraulic or pneumatic installation: Utilize a plunger or } \\
\text { piston to increase the level. } \\
\text { Utilize a plunger or piston to expel liquid from the recipient. }\end{array}$ \\
\hline $\begin{array}{l}\text { If residue accumulation is reduced, } \\
\text { eliminated, or neutralized by cleaning } \\
\text { the compartment with every cycle, than } \\
\text { the impracticality of the system grows } \\
\text { worse. }\end{array}$ & $\begin{array}{l}\text { Undesirable factors } \\
\text { acting in an object }(30) \times \\
\text { User convenience }(33)\end{array}$ & $\begin{array}{l}2 \text { - Extraction: Remove the "vehicle" of the softener so as to leave } \\
\text { only those substances of interest. } \\
25 \text { - Auto-service: The shape of the recipient and the addition of } \\
\text { the water should permit the dilution of the softener and its own } \\
\text { cleaning after each cycle. } \\
28 \text { - Substitution for a mechanical system: Use a system similar to } \\
\text { the water mill. } \\
29 \text { - Use a hydraulic or pneumatic installation: Utilize a plunger or } \\
\text { piston to increase the level. } \\
\text { Utilize a plunger or piston to expel liquid from the recipient. }\end{array}$ \\
\hline
\end{tabular}


With the aid information gathered on the ISQ, the concepts 4 (obtained through patent research) and 8 (generated through the use of TRIZ/SI) were chosen as the best and most viable, and went on to the stages of prototyping and testing.

\subsection{Case 2 - pipe welding}

In this case, TRIZ/SI was applied to solve problems in the welding process of industrial pipes, specifically in the area of petrochemicals.

In this branch, the quality of the welding is very important since the pipes have a 20 year life expectancy. At the same time, it is difficult to reach the high demands, considering the short deadlines and the operations performed in the field.

A problem that occurs during this process is the lack of fusion between the welded joints, which generates a concentration of tensions and, consequently, risks of material failure. The principle cause for this lack of fusion is the misalignment between the joints that should be welded. These parts arrive from the supplier with a certain degree

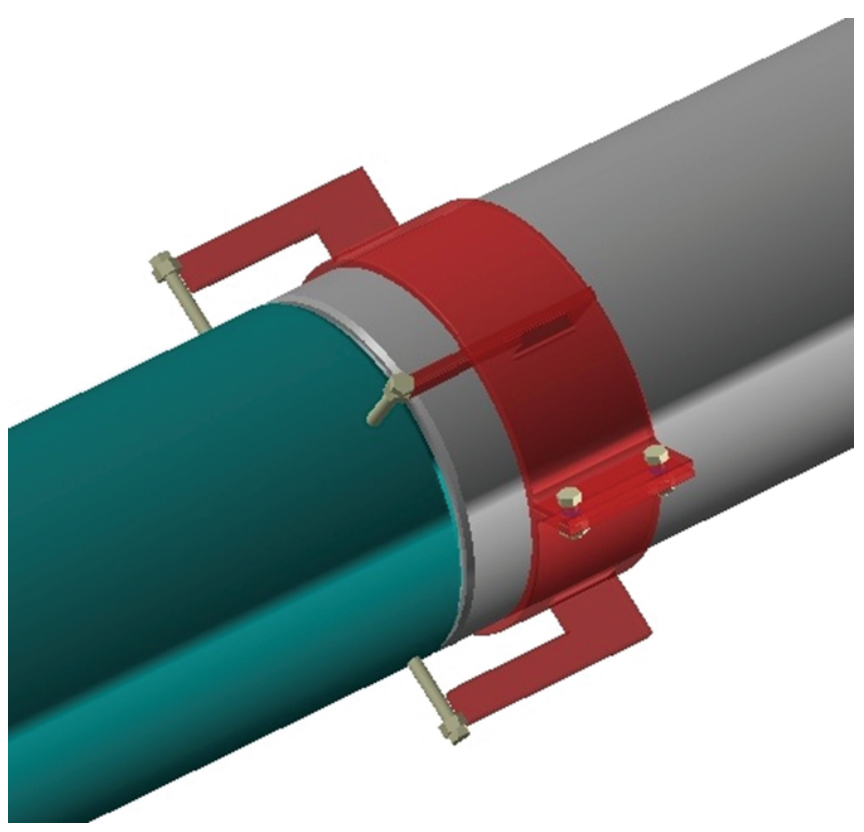

Figure 2. Pipes to be welded and the coupler (BUZINARO, 2009).

Table 3. Morphological Matrix for the New Softener Distribution System (BRANDALIZE, 2009).

\begin{tabular}{|c|c|c|c|c|c|}
\hline \multicolumn{2}{|r|}{ Functions } & \multicolumn{4}{|c|}{ Operational principles } \\
\hline 1 & Clean dispenser & $\begin{array}{c}\text { Auto-cleaning } \\
\text { program }\end{array}$ & $\begin{array}{l}\text { The most simple } \\
\text { system geometry } \\
\text { possible }\end{array}$ & $\begin{array}{l}\text { Removable } \\
\text { system }\end{array}$ & - \\
\hline 2 & Supply dispenser & Drawer & $\begin{array}{l}\text { Hollow at the top } \\
\text { of the machine }\end{array}$ & $\begin{array}{c}\text { Hollow in the } \\
\text { agitator }\end{array}$ & Hollow in the basket \\
\hline 3 & $\begin{array}{c}\text { Activate the electro- } \\
\text { valve }\end{array}$ & Electric signal & - & - & - \\
\hline 4 & $\begin{array}{l}\text { Add water to } \\
\text { the softener } \\
\text { compartment }\end{array}$ & $\begin{array}{c}\text { Concentrated jet of } \\
\text { water }\end{array}$ & $\begin{array}{c}\text { A single jet, } \\
\text { but one which } \\
\text { distribute the water }\end{array}$ & $\begin{array}{c}\text { Various } \\
\text { application } \\
\text { points for the } \\
\text { water }\end{array}$ & - \\
\hline 5 & Dilute the softener & $\begin{array}{l}\text { Geometry of } \\
\text { the recipient } \\
\text { (turbulence) }\end{array}$ & $\begin{array}{l}\text { Various application } \\
\text { points for the water }\end{array}$ & Rotating device & Modify the properties so as to permit draining \\
\hline 6 & $\begin{array}{c}\text { Exceed the } \\
\text { maximum level } \\
\text { indicated for the } \\
\text { compartment }\end{array}$ & $\begin{array}{c}\text { Begin the siphon } \\
\text { effect }\end{array}$ & $\begin{array}{l}\text { Overflow of the } \\
\text { recipient content }\end{array}$ & $\begin{array}{l}\text { Toppling the } \\
\text { system }\end{array}$ & Use of the plunger or piston \\
\hline 7 & $\begin{array}{c}\text { Elevate the level of } \\
\text { mixture within the } \\
\text { compartment }\end{array}$ & $\begin{array}{l}\text { Add water to the } \\
\text { recipient }\end{array}$ & - & - & - \\
\hline 8 & $\begin{array}{c}\text { Transform energy } \\
\text { in order to promote } \\
\text { draining }\end{array}$ & Different pressures & Gravity & Mechanism & Centrifugal force \\
\hline 9 & Drain fluid & $\begin{array}{l}\text { Tube connecting the } \\
\text { recipient to the tank }\end{array}$ & $\begin{array}{c}\text { Application } \\
\text { between the tank } \\
\text { and the basket, } \\
\text { over the rinse } \\
\text { water }\end{array}$ & $\begin{array}{c}\text { Application } \\
\text { within the basket, } \\
\text { over the clothes }\end{array}$ & Application in the basket, over the rinse water \\
\hline 10 & $\begin{array}{l}\text { Clean dispenser } \\
\text { (auto-cleaning) }\end{array}$ & $\begin{array}{c}\text { Auto-cleaning } \\
\text { program }\end{array}$ & $\begin{array}{l}\text { The most simple } \\
\text { system geometry } \\
\text { possible }\end{array}$ & $\begin{array}{l}\text { Removable } \\
\text { system }\end{array}$ & - \\
\hline
\end{tabular}


of discontinuity. Therefore, it is necessary to carry out a thorough preparation in order to avoid that the misalignment between the pipes being welded does not cause a lack of fusion in the welding process. The inspection for this degree of misalignment is done by a welding inspector with the aid of a measuring device called Hi-Lo.

Aside from the inspection with the Hi-Lo, many companies utilize a device called coupler, also known as a spider, whose function is to force the pipes to align, although in some cases it is incapable of correcting the misalignment (Figure 2).

It is against this backdrop that TRIZ/SI was applied, seeking out solutions so that the welding may be done more efficiently and the norms fulfilled.

In formulating the problem, the method called Fault Tree Analysis (LEE, 1985) was utilized, which helped to determine the intermediate and primary events related to the lack of fusion, pointing out that the undesired event was occasioned by the misalignment of the piping.
Following this, a TRIZ/SI tool called System Operator (DE CARVALHO, 2007) was utilized. At this stage, the technical system was evaluated at its three levels (subsystem, system, and supersystem), and at three instants (past, present, and future). The schematic of this analysis is shown in Table 5.

To complete the analysis of the problem, another tool from TRIZ/SI was used, the Ideal Final Result (IFR) (DE CARVALHO, 2007). In this case, such questions were asked as: What is the objective of the final system? What is the Ideal Final Result (IFR)? What prevents reaching the IFR?

In solving the problem, the Method of Inventive Principles (MIP) was the first tool of choice. In previous stages, analyses of the problem were conducted, facilitating the identification of the engineering parameters of the contradiction to be applied in the Contradictions Matrix $(\mathrm{CM})$, as shown in Table 6.

Table 4. Concepts that were generated after the application of the MIP (BRANDALIZE, 2009).

\begin{tabular}{|c|c|c|}
\hline Concept 1 - Funnel & Generated Concepts \\
\hline $\begin{array}{c}\text { Concept 2 - Superficial } \\
\text { tension - Drawer }\end{array}$ & Concept 5 - Sprinkler type mixer \\
\hline $\begin{array}{c}\text { Concept 3 - Superficial } \\
\text { tension - Hollow at the upper } \\
\text { part of the machine }\end{array}$ & Concept 7 - Tipping shovels \\
\hline $\begin{array}{c}\text { Concept } 4 \text { - Water mill } \\
\text { Concept } 8 \text { - Mini-turbine }\end{array}$ & C - Rotating tray \\
\hline
\end{tabular}

Table 5. Schematic of the Analysis Utilizing the System Operator (BUZINARO, 2009).

\begin{tabular}{|c|c|c|c|}
\hline & Past & Present & Future \\
\hline Supersystem & $\begin{array}{c}\text { Alignment utilizing the } \\
\text { piping and accessories with a } \\
\text { docking tool and screw }\end{array}$ & $\begin{array}{c}\text { Piping and accessories, with an } \\
\text { auto-alignment system }\end{array}$ & $\begin{array}{c}\text { Piping and accessories, with } \\
\text { an auto-alignment system }\end{array}$ \\
\hline System & $\begin{array}{c}\text { Alignment done with the } \\
\text { use of a fixed manual } \\
\text { coupler - like a clamp }\end{array}$ & $\begin{array}{c}\text { Alignment done with the use } \\
\text { of a manual coupler with } \\
\text { adjustable positioning }\end{array}$ & $\begin{array}{c}\text { Alignment done by utilizing } \\
\text { a pneumatic coupler with } \\
\text { positioning sensors }\end{array}$ \\
\hline Subsystem & $\begin{array}{c}\text { Alignment done by utilizing a } \\
\text { belt, hinge, and coupling }\end{array}$ & $\begin{array}{c}\text { Alignment done with a belt, fasteners, } \\
\text { and positioning screws }\end{array}$ & $\begin{array}{c}\text { Alignment done by utilizing a } \\
\text { pre-positioner }\end{array}$ \\
\hline & Past & Present & Future \\
\hline
\end{tabular}


Table 6. Application of the MIP (BUZINARO, 2009).

\begin{tabular}{|c|c|}
\hline Step & Description \\
\hline $\begin{array}{l}\text { 1) Reformulation of the technical contradiction } \\
\text { identified in relation to the engineering parameters }\end{array}$ & 37 - Complexity of control vs. 36 - Complexity of the Object \\
\hline $\begin{array}{l}\text { 2) Identification of the inventive principles to be } \\
\text { applied with the use of the Contradictions Matrix }\end{array}$ & $\begin{array}{l}\text { For the contradicting parameters } 37 \text { and } 36, \text { the contradictions matrix suggests } \\
\text { the following IP: } \\
15 \text { - Streamlining; } \\
10 \text { - Prior action; } \\
28 \text { - Substitution of mechanical means; } \\
37 \text { - Thermal Expansion }\end{array}$ \\
\hline $\begin{array}{l}\text { 3) Application of the inventive principles to resolve the } \\
\text { contradiction }\end{array}$ & $\begin{array}{l}\text { With the application of PI } 15 \text { - Streamlining, the following idea was generated: } \\
\text { - Insert a beveling function in the pipe coupler, so that the bevel effect occurs in } \\
\text { the same position as the parts will be welded. } \\
\text { With the application of PI } 10 \text { - Prior Action, the following idea was generated: } \\
\text { - On preparing the bevel of the tube/accessory the operator verifies the ovality, } \\
\text { alterations in the thickness, and then makes the assembly of the belt positioning } \\
\text { of the tube, for later assembly of the coupler. } \\
\text { With the application of } 28 \text { - Substitution of mechanical means, the following } \\
\text { idea was generated: } \\
\text { - Include positioning sensors, to verify the alignment and the root gap, directly } \\
\text { linked to automated actuators in the coupling device, increasing efficiency in } \\
\text { positioning. } \\
\text { With the application of PI } 37 \text { - Thermal Expansion, the following idea was } \\
\text { generated: } \\
\text { - The use of a flange with electric resistors, so that the greater thermal dilation at } \\
\text { the extremities of the pipe makes the adaptation and ovality correction needed in } \\
\text { the tube }\end{array}$ \\
\hline
\end{tabular}

Table 7. Possible Separations Applicable to the Problem (BUZINARO, 2009).

\begin{tabular}{|c|l|}
\hline $\begin{array}{c}\text { Principle of } \\
\text { separation }\end{array}$ & \multicolumn{1}{c|}{ Description } \\
\hline Separation in space & $\begin{array}{l}\text { The coupler may be internal at some points } \\
\text { with a few claws, and external at every } \\
\text { other position. }\end{array}$ \\
\hline Separation in time & $\begin{array}{l}\text { The claws can remain internal during the } \\
\text { alignment, and external after, to position/ } \\
\text { adjust the root gap and bridging between } \\
\text { the parts. }\end{array}$ \\
\hline $\begin{array}{c}\text { Separation } \\
\text { according to } \\
\text { condition }\end{array}$ & $\begin{array}{l}\text { The coupler may be internal at the } \\
\text { beginning of the coupling and external } \\
\text { upon positioning the root gap and bridging. }\end{array}$ \\
\hline $\begin{array}{c}\text { Separation in the } \\
\text { system }\end{array}$ & Not applicable. \\
\hline
\end{tabular}

The last method utilized was the Method of Separation (MS). The physical contradiction found in this problem is that the coupler should be inside the piping and it should be outside the piping. It should be inside because then the best alignment is possible, and it should be outside because otherwise its removal is impossible.

The possible separations are listed in Table 7.

From the previous stages, 7 ideas were generated that might serve as a solution to the problem. Two of them were considered as the ideas with the greatest potential for practical application:

- perform a prior operation of verification and correction of ovality during the beveling, completing the assembly of a "belt" which would serve as a basis for assembling the coupler and reducing the assembly time of the same;

- add claws to the coupler for internal fastening, but which have the shaft thickness or diameter equal to the root gap, whereas the shaft should also have a scale for verifying the tolerance for misalignment.

\section{Conclusions}

In this article, two cases illustrating the application of TRIZ/SI were presented, showing how the resolution of problems might be guided in a systematic and efficient way, either at the conceptual design stage (case 1) or at the process design stage (case 2).

Upon applying TRIZ/SI, the problem-solver is capable of visualizing the problem in a clearer and more complete manner, not attempting to reach the solution by launching directly from the specific problem, but through the abstraction of the problem, searching for generic solutions contained in the body of knowledge of TRIZ/SI, and then achieving specific solutions. Through the process, one gains the depth of knowledge necessary to generate more creative solutions. 


\section{References}

BRANDALIZE, G. G. Desenvolvimento de dispenser automático de amaciante para lavadora de roupa. 2009. Monografia (Graduação em Engenharia Industrial Mecânica)-Universidade Tecnológica Federal do Paraná, Curitiba, 2009.

BUZINARO, C. G. Aplicação da TRIZ na Montagem de Tubulações Industriais. 2009. Monografia (Especialização em Gestão de Desenvolvimento de Produto)-Universidade Tecnológica Federal do Paraná, Curitiba, 2009.

DE CARVAlHO, M. A.; MARTINS, E. O. Solving an Automotive Assembly Problem Using TRIZ. In: IBEROAMERICAN TECHNOLOGICAL INNOVATION CONGRESS, 5., 2010. Minutes... México, 2010.
DE CARVALHO, M. A. Metodologia Ideatriz para Ideação de Novos Produtos. 2007. Tese (Doutorado em Engenharia de Produção)-Universidade Federal de Santa Catarina, Florianópolis, 2007.

ORLOFF, M. A. Inventive Thinking through TRIZ - A Practical Guide. Springer, 2003.

SAVRANSKY, S. D. Engineering of Creativity: Introduction to TRIZ Methodology of Inventive Problem Solving. New York: CRC, 2000. http://dx.doi.org/10.1201/9781420038958

TERNINKO, J.; ZUSMAN, A.; ZLOTIN, B. Systematic Innovation: An Introduction to TRIZ (Theory of Inventive Problem Solving). Boca Raton: CRC Press, 1998. 